\title{
Pneumatosis intestinalis with pneumobilia
}

\author{
Murtaza Rashid ำ, Majed Aljohani, Bandar Al Mufareh
}

Emergency Medicine, Royal Commission Hospital in Jubail, Jubail, Saudi Arabia

\section{Correspondence to Dr Majed Aljohani;} mjohani@hotmail.com

Accepted 25 May 2021

\section{DESCRIPTION}

A 58-year-old patient came to our emergency department with abdominal pain and constipation for 1 day. Patient had a history of diabetes mellitus, hypertension, coronary artery disease and end stage renal disease and was on regular haemodialysis. His Blood Pressure was 86/59; Pulse rate, 98; Tempreture, $36.7^{\circ} \mathrm{C} ; \mathrm{O}_{2}, 99 \%$ and Glascow Coma Scale, $15 / 15$. On examination, abdomen was mildly distended though soft and non-tender. A plain radiograph of the abdomen was performed. Abdominal X-ray showed dilated caecum containing concentric air in the bowel wall suggesting bowel ischaemia (figure 1). Subsequently abdominal CT scan of abdomen was performed which confirmed the dilated caecum and ascending colon with intramural circumferential air (figure 2A,B). Intramural air extended upto distal ileum. Interestingly, air was also seen in intrahepatic bile ducts extending till periphery of the left lobe (figure 2C). ECG did not show atrial fibrillation and echocardiogram ruled out any intracardiac thrombus. His inflammatory markers were very high (White Blood Cells, 24 600; Haemoglobin, 14.6; C-Reactive Protein, 514.5; lactate, 5.6; procalcitonin, 96.69). Our impression was pneumatosis intestinalis along with pneumobilia due to bowel ischaemia. Patient underwent laparotomy and terminal $75 \mathrm{~cm}$ of ileum and ascending colon were found to be gangrenous which were resected and end to end anastomosis was performed. Biopsy findings were consistent with non-viable mucosa and thrombosed vessels in the mesentery. Postoperative course in the hospital and follow-up was uneventful. The most common

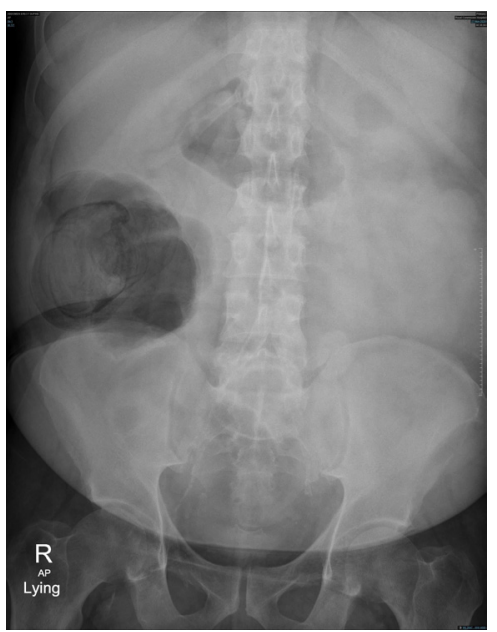

Figure 1 An anterioposterior radiograph of the abdomen showing dilated caecum on the right side containing concentric air rings in the bowel wall.

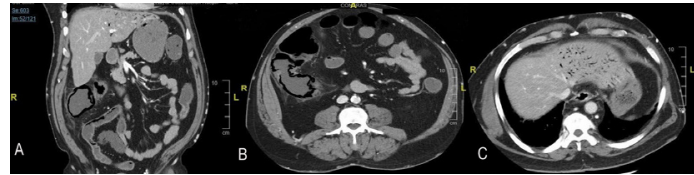

Figure 2 A coronal section (A) and transverse section (B) of the abdominal CT scan confirming the intramural gas in bowel extending up to the liver bile ducts (C).

emergent causes of intramural bowel gas are the result of bowel necrosis due to infarction, necrotising enterocolitis and volvulus. ${ }^{1}$ About 50\% of the patients with pneumatosis intestinalis can be managed conservatively but the presence of additional portal vein gas causes higher mortality rate. ${ }^{2}$ Prompt recognition with the help of clinical examination, imaging and laboratory findings and involving a surgeon early in the course in the emergency department is quintessential in the management of bowel ischaemia which otherwise carries a high rate of mortality.

\section{Learning points}

Soft and non-tender abdomen especially in a patient with comorbidities does not guarantee a benign condition.

- Patients with diabetes mellitus have altered pain processing. Pain is not always out of proportion.

- Do not overlook plain radiographs in busy emergency department. There might be a big clue.

Twitter Murtaza Rashid @DrMurtazaRashid

Contributors MR contributed to drafting the manuscript, revising it critically for intellectual content. MA contributed to the acquisition of data, drafting the manuscript and has agreed to be accountable for the article. BA contributed to the conception, design, interpretation of data, final approval of the version sent for publication and agreed to be accountable for the article.

Funding The authors have not declared a specific grant for this research from any funding agency in the public, commercial or not-for-profit sectors.

Competing interests None declared.

Patient consent for publication Obtained.

Provenance and peer review Not commissioned; externally peer reviewed.

ORCID iD

Murtaza Rashid http://orcid.org/0000-0002-1976-4524

\section{REFERENCES}

1 Pear BL. Pneumatosis intestinalis: a review. Radiology 1998;207:13-19.

2 Morris MS, Gee AC, Cho SD, et al. Management and outcome of pneumatosis intestinalis. Am J Surg 2008;195:679-83. 
Images in...

Copyright 2021 BMJ Publishing Group. All rights reserved. For permission to reuse any of this content visit https://www.bmj.com/company/products-services/rights-and-licensing/permissions/

BMJ Case Report Fellows may re-use this article for personal use and teaching without any further permission.

Become a Fellow of BMJ Case Reports today and you can:

- Submit as many cases as you like

- Enjoy fast sympathetic peer review and rapid publication of accepted articles

Access all the published articles

Re-use any of the published material for personal use and teaching without further permission

Customer Service

If you have any further queries about your subscription, please contact our customer services team on +44 (0) 2071111105 or via email at support@bmj.com.

Visit casereports.bmj.com for more articles like this and to become a Fellow 